\title{
The future of the pig as a meat animal
}

By V. R. Fowler, Rowett Research Institute, Bucksburn, Aberdeen $A B 2{ }_{9} S B$

In his book 'Cheape and Good Husbandry' published in 1614, Gervase Markham described pigs as '...troublesome, noisome, unruly and great ravenours ... the Husbandmans Best Scavenger, and the Huswifes most wholesome sinke'. The versatility of the pig in eating a wide range of organic material and producing highly prized meat is legendary and it has long been an integral part of the rural economy of peasants whose religious views did not disallow it. In industrial societies, the pig has had the misfortune to be physiologically amenable to a high degree of intensification. Its lack of hair, liking for warmth, and willingness to lie 'cheek by jowl' with its neighbours has meant that it can survive in crowded, dirty, warm, wet quarters in which other farm animals covered in wool, hair or feathers would become caked with excrement and quickly succumb to infection. Its other biological attributes include outstanding prolificacy, potentially $25-30$ offspring/sow per year, and a prodigious potential growth rate of nearly $\mathrm{I} \mathrm{kg} / \mathrm{d}$ from birth to slaughter.

Its versatility continues after death with a wider variety of processed foods originating as pig tissue than for any other farm animal. It is little wonder, therefore, that the pig has found formidable support to champion its cause as a meat producing animal: indeed $\mathrm{Dr}$ Braude wrote in a similar paper read to this society a decade ago that he had 'no difficulty in foreseeing a rosy future... particularly for pig production'. (Braude, 1970).

In the time of Gervase Markham statements about what would come to pass were the preserve of prophets and clairvoyants. Today, the tools of science are employed in the business of prediction in the shape of weather satellites and computerized analysis of trends. Indeed the strategy of present scientific research depends heavily on being able to foresee not only the most likely technical developments, but the social and political ones as well. The task is daunting

Table 1. Comparison of the population in the United Kingdom of humans and pigs (millions)

$\begin{array}{cccc} & \text { Pigs } & \begin{array}{c}\text { Consumption of pork, } \\ \text { bacon and ham } \\ \text { (kg/head per year) }\end{array} \\ 195^{8} & 51 \cdot 7 & 6 \cdot 5 & 20 \cdot 2 \\ 1968 & 55 \cdot 0 & 7 \cdot 8 & 21 \cdot 8 \\ 1977 & 56 \cdot 0 & 7 \cdot 7 & 20 \cdot 4 \\ \cdot 1978 & (57 \cdot 5) & (9 \cdot 2) & (24 \cdot 0)\end{array}$

-Predicted by Braude (1970). 


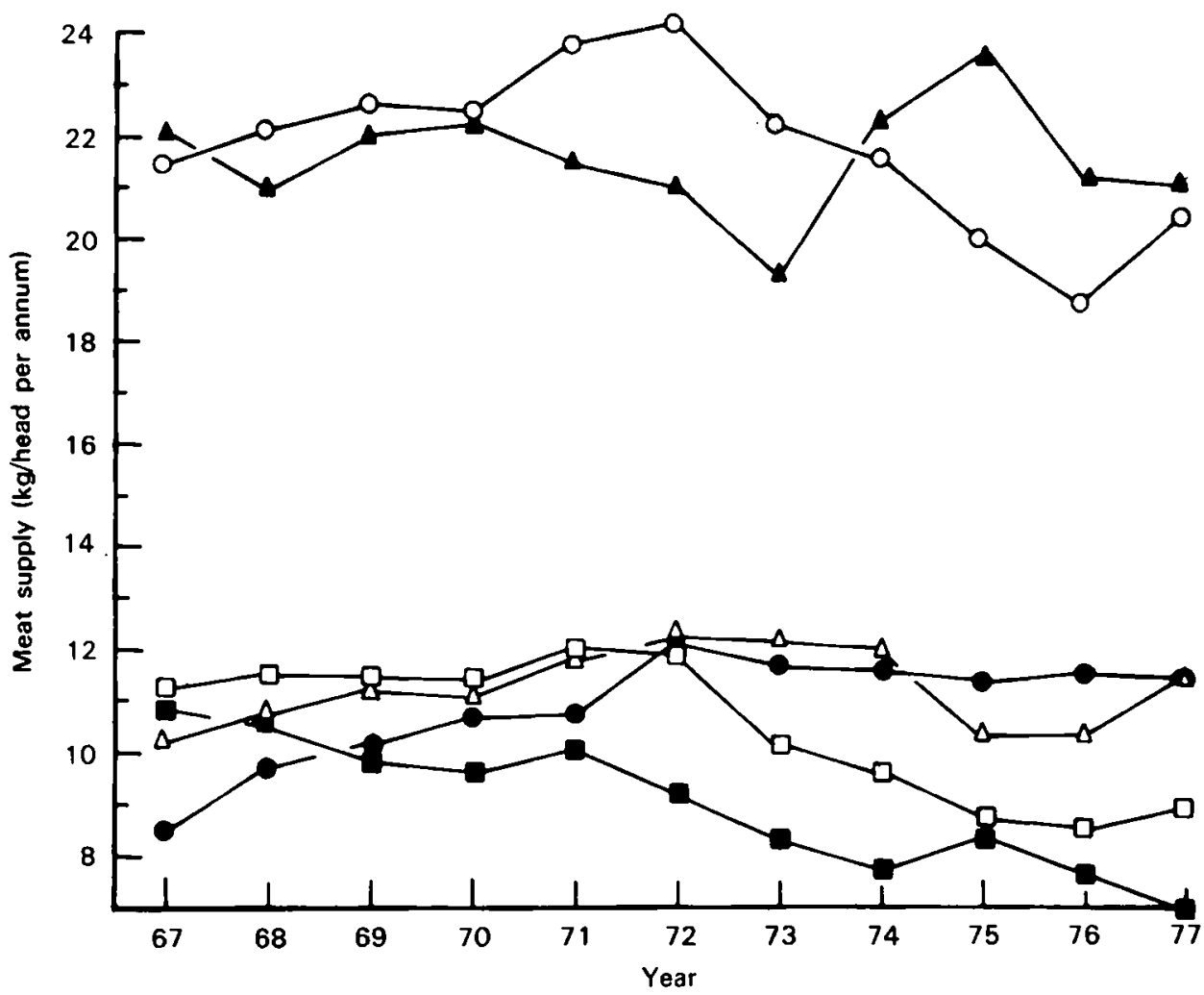

Fig. I. Meat supply per capita 1967-1977. (Central Statistical Office, 1979). Beef $\bigcirc-0$, poultry $-\triangle$, pork $\Delta \longrightarrow \Delta$, total pig meat $\triangle \longrightarrow \Delta$, ham $\square \longrightarrow \square$, lamb and mutton

because the interactions are becoming more complex, and in many aspects of technological development we are beginning to realize that what is possible may not be desirable.

\section{Recent changes in production and consumption}

Braude (1970) examined the trends in the production and consumption of pig meat which applied at the time and then attempted a prediction of what might happen in the following 10 or 20 years. Although his intention was to give a qualitative rather than a quantitative indication of change, it is of interest to examine the extent to which his expectations have been fulfilled. The actual trends in the population of humans and pigs and in pig meat consumption are shown in Table I, together with the predicted values. Growth of the human population slowed down to a greater extent than expected and the anticipated growth in pig meat consumption per capita failed to materialize. A more detailed analysis of the trend is given in Fig. I, which shows changes in the consumption per capita of all kinds of meat over the years from 1967 to 1977 , taken from information produced by the Central Statistical Office. Over the period, beef consumption remained fairly constant apart from the period of shortage and high prices in 1973. Consumption 
Table 2. Changes in the pig populations of the world and of locations with significant numbers of pigs (millions) and the relationship to the human population*

\begin{tabular}{|c|c|c|c|c|}
\hline World & $625 \cdot 2$ & $731 \cdot 8$ & 17.1 & 0.17 \\
\hline Europe & $132 \cdot 4$ & 167.0 & $26 \cdot I$ & 0.35 \\
\hline UK & $8 \cdot 2$ & $7 \cdot 8$ & $-5 \cdot 3$ & $0 . \mathbf{r}_{4}$ \\
\hline West Germany & $19 \cdot 7$ & $21 \cdot 4$ & 8.6 & 0.35 \\
\hline Poland & $14 \cdot 3$ & $21 \cdot 7$ & $5 I \cdot 3$ & 0.62 \\
\hline Denmark & $8 \cdot 3$ & $8 \cdot 0$ & $-3 \cdot 6$ & $1 \cdot 63$ \\
\hline North and Central America & $85 \cdot 9$ & 83.8 & $-2 \cdot 4$ & 0.24 \\
\hline South America & $45 \cdot 2$ & $54 \cdot 7$ & $21 \cdot 0$ & 0.24 \\
\hline USSR & 57.5 & $70 \cdot 5$ & $18 \cdot 4$ & 0.27 \\
\hline China & $246 \cdot 3$ & $288 \cdot 3$ & $17 \cdot 1$ & 0.33 \\
\hline
\end{tabular}

-Food and Agriculture Organization (1979).

of poultry meat increased by about $3 \mathrm{~kg} /$ head per annum whilst that of lamb fell by about $4 \mathrm{~kg}$. Consumption of bacon and ham fell by about $2.5 \mathrm{~kg}$ and consumption of pork rose by about $\mathrm{I}$ kg.

The trends are quite clear; over-all consumption of meat has hardly changed but about one-third of the lamb consumption has been replaced by poultry and oneeighth of the bacon and ham by pork. The factors contributing to the changes are complex but may be associated with the substitution of leaner meats for fatty ones and with the decline of the 'English' breakfast, in favour of one based on breakfast cereals alone the consumption of which rose by over a third.

Some statistics on changes in the world population of pigs and in areas having a major interest in pig production are given in Table 2. The pig population in the UK dropped by about $5 \%$ over 8 years compared with a general increase of

Table 3. Pig production in relation to other agricultural output in UK in $1977^{\circ}$

\begin{tabular}{|c|c|c|c|}
\hline & $6 \mathrm{~m}$ & $\begin{array}{l}\text { Percentage of } \\
\text { total } \\
\text { meat }\end{array}$ & $\begin{array}{c}\text { Percentage of } \\
\text { total } \\
\text { agricultural } \\
\text { production }\end{array}$ \\
\hline \multicolumn{4}{|l|}{ Meat } \\
\hline Pigs & $54 \mathrm{I}$ & $30 \cdot 1$ & I I $\cdot \mathbf{I}$ \\
\hline Sheep & 177 & $9 \cdot 8$ & $3 \cdot 6$ \\
\hline Poultry & 3 II & $17 \cdot 2$ & $6 \cdot 3$ \\
\hline Cattle & $74^{8}$ & $41 \cdot 5$ & $15 \cdot 3$ \\
\hline Other & 24 & $1 \cdot 3$ & 0.4 \\
\hline Total meat & 1800 & - & $36 \cdot 9$ \\
\hline \multicolumn{4}{|l|}{ Other livestock products } \\
\hline (wool, milk, eggs) & 1473 & - & $30 \cdot 2$ \\
\hline Total livestock output & 3273 & - & $67 \cdot 7$ \\
\hline Total agricultural output & 4880 & - & - \\
\hline
\end{tabular}


about $17 \%$ on a world basis and a $51 \%$ rise in the particular case of Poland. In terms of the areas listed, the pigs per capita in the UK was the lowest of all. Part of the explanation lies of course with the fact that over half the supply of bacon and ham is imported into the country (the annual review forecast for 1978 was $58 \%$ ). Despite this, the pig industry is a very significant part of agriculture in the UK, its output having a gross annual value of $\$ .54 \mathrm{Im}$ in 1977 which was nearly one-third of the total value of all meat animals, and more than $10 \%$ of the value of the over-all output of agriculture (Table 3 ).

\section{The biological potential for production}

In assessing the future of the pig for meat production, it is important to realize that there are definite limits to the improvements which can be achieved by genetics, nutrition and management. In the past, we became accustomed to the idea that the intrinsic fatness of pigs fed on cereal-based diets was an almost inexhaustible fund of 'wasted' energy which could be saved by the orchestrated application of physiological principles. Three developments in the UK have made this particular problem appear very much less important than before. First, there has been a swing towards pork production as mentioned above and, associated with it, a reduction of slaughter weight. Secondly, the castration of male pigs has been abandoned for light pork pigs, and there are indications that producers of bacon pigs will follow suit. Thirdly, the impact of breeding companies on the national herd has been very considerable, and the comparatively high heritabilities for backfat thickness have led to rapid improvements in this trait (Fowler et al. 1976). The combination of these factors has brought about the previously almost unthinkable complaint that some pigs are already too lean. If this becomes more generally true, then we could quickly regret breeding policies which have led to a reduction in the pig's voluntary intake since increasing it would be one of the few avenues left for genetic improvement (Smith \& Fowler, 1979).

The forecasts of Dr Braude for growth have proved remarkably accurate when compared with the results of pigs submitted to the Meat and Livestock

Table 4. Comparison of the performance of pigs as predicted by Braude (1970) for $197^{8}$ and the performance of pigs (mean and best three companies) reported in 1976-1978 by the Meat and Livestock Commission (MLC, 1978) for their scheme for Commercial Product Evaluation (CPE)

$\begin{array}{lcccc} & & & \text { CPE } & \\ & \text { rg68 } & & \text { Best } & \text { CPE } \\ & \text { Excellent } & 1978 & 3 & \text { Mean } \\ \text { Daily gain } 20-90 \mathrm{~kg}(\mathrm{~g} / \mathrm{d}) & 730 & 860 & 861 & 85^{2} \\ \text { Gain:feed value } 20-90 \mathrm{~kg}(\mathrm{~kg} / \mathrm{kg}) & 3 \cdot 0 & 2 \cdot 7 & 2 \cdot 8 & 2 \cdot 9 \\ \text { Pigs/sow per year } & 22 & 24^{*} & (19 \cdot 2 \dagger) & (18 \cdot 1 \ddagger)\end{array}$

-This was assumed to be without artificial rearing. tMLC recorded herds 'best third'. ¥MLC recorded herds mean. 
Commission for commercial product evaluation (Table 4). Indeed, if such progress were maintained, there seems to be every likelihood that his targets for 1988 of growth rates of $1000 \mathrm{~g}$ and gain:feed values of 2.2 will be achieved. The productivity of sows, however, presents a rather different story. Early-weaning at about $21 \mathrm{~d}$ of age is now widely practised but we are still some way from achieving the full potential of the system because of the twin problems of sow fertility and mortality of the newborn.

A key issue raised by Braude (1970) was the potential productivity of the sow if a system of artificial rearing of piglets were adopted. Those who have attempted such an approach will know well the frustrating problems of variable performance and sporadic high mortality. There is not space to develop the theme here, but in our programme of work on the topic at the Rowett Institute we are exploring the hypothesis that it may be better to separate the piglet from the sow at the moment of birth so that piglets are produced having a health status approaching that of hysterectomy derived animals, but delivered per via naturalis. This avoids to some extent the difficulties of uncontrolled contamination with pathogens and the variable amounts of transferred passive immunity associated with even a brief period of suckling. The problems then become ones of a smooth induction of active immunity by a programme of oral vaccination, and bringing the sow to a fertile oestrus as rapidly as possible.

In the context of maximizing sow productivity, it is surprising that there has been no uptake by the industry of the high biological efficiency of systems which utilize once-bred gilts slaughtered for meat after delivery of their first litter (MacPherson et al. 1977). Such an approach could eventually be combined with weaning at birth to produce something very close to the ultimate in attainable reproductive efficiency in the pig. Even if such a system proved feasible, many questions would need to be answered concerning its desirability.

\section{The use of resources in pig production}

Over the last decade, there has been a much greater awareness that some resources are very definitely finite. Moreover, they are being increasingly competed for by countries of the Third World, whose societies have ambitions for achieving levels of consumerism approaching those taken for granted in the West. There are also many ecologically-minded people who have been quick to point out that diets for simple stomached pigs could almost equally well form sound nutrition for simple stomached (and in many cases malnourished) humans. The philosophical ramifications of this dilemma baffle many finer minds than mine, and I shall restrict myself to a very few observations. First, China with nearly one-quarter of the world's population in only a moderately sized area of agriculturally productive land in the eastern part of the country also supports one pig for every three people (Table 2). Secondly, in terms of other meat-producing animals, the pig compares quite favourably both for output of edible product/hectare and in its use of support energy (Table 5). The calculations show, perhaps surprisingly, that in both respects the pig is always more efficient than either beef or sheep. Too much 
Table 5. Utilization of land and support energy in agricultural production

\begin{tabular}{|c|c|c|}
\hline & \multicolumn{2}{|c|}{ Edible yield per hectare ${ }^{\circ}$} \\
\hline & $\begin{array}{l}\text { Energy } \\
\left(\mathrm{MJ} \times 10^{3}\right)\end{array}$ & $\begin{array}{l}\text { Protein } \\
\quad(\mathrm{kg})\end{array}$ \\
\hline Potatoes & 100 & 420 \\
\hline Wheat & $5^{8}$ & $35^{\circ}$ \\
\hline Dairy & IO & I I 5 \\
\hline Pigs & 8 & $5^{\circ}$ \\
\hline Broilers & 5 & 92 \\
\hline Beef & 3 & 27 \\
\hline Sheep & 2 & 23 \\
\hline
\end{tabular}

Support energy to produce

•From Holmes (197I). TFrom White (1975).

reliance should not be given to the generality of such figures, but they indicate that intensive animal production is not necessarily expensive and wasteful of resources.

Another interesting question in this context relates to the ability of the pig to utilize the waste food materials of urban society, substandard agricultural produce and high yielding bulky feeds such as fodder beet, forage rape and stock-feed potatoes. Swill-feeding, the use of whey and skimmed milk are well established commercial practices and need no comment. Uncooked bulky feeds, however, produce a number of technical problems. Nutrients in such feeds are usually well wrapped in cell walls high in cellulose. There is a very limited ability to ferment cellulose in the caecum and colon, and though sows may be able to eat and ferment sufficient of a fibrous diet to supply a high proportion of their maintenance requirement, they will be in steady negative energy and protein balance. The problem is essentially that the digestibility of such diets falls as the intake is increased. Experiments by my colleagues (Hovell and Stevens, unpublished results) have shown that even pregnant sows given fresh grass ad lib. require up to $1 \cdot 5 \mathrm{~kg}$ barley/d to meet their nutrient requirements. The problem is perhaps more acute in growing pigs as has also been shown in a series of experiments by my colleagues (Livingstone \& Jones, 1977; Livingstone et al. 1977). In general, the introduction of a bulky feed reduces the intake of digestible organic matter and results in slower growth. Whilst such a strategy might make sense in an extensive production system, it is a considerable disadvantage in a highly capitalized piggery where turnover is paramount and the volume of effluent an embarrassment. My own view is that the cheap processing of bulky feeds to make the nutrients more available is a major area for further research.

\section{The environment, social factors and animal welfare}

Units with 500 sows or more were once a rarity but are now increasingly common. There are also signs that feedstuff manufacturers, producer groups and processors are forming business arrangements which put the industry well on the road to the vertically integrated structure of the poultry industry. There seem to be few reasons why the tendency towards very large units should not continue since 
they offer scope for the appointment of people having high-class expertise, for computer control and perhaps for microprocessors. Ironically, one of their main problems, that of disposing of effluent, might actually be helped by large scale, since the economics of anaerobic digestion of waste to methane improve with size (Hobson et al. 1979).

In crowded Britain, however, intensive animal production with its odours, noise and effluent is in conflict with other legitimate demands on the countryside. The report of the Royal Commission on Environmental Pollution (Kornberg, 1979) recommends that intensive animal units should come under the same planning regulations as do industrial enterprises. This would represent a major increase in control and would undoubtedly result in a greater capital cost for which the consumer must eventually pay. There are indications too that society is becoming very disturbed about the conditions which animals reared in intensive livestock units must endure. The concern is not new. A spate of books in the early sixties such as Silent Spring by Rachael Carson (1963), Animal Machines by Ruth Harrison (1964) and Brave New Victuals by Elspeth Huxley (1965) brought a wave of public awareness that culminated in the setting up of a Technical Committee on the Welfare of Animals. Its recommendations (Brambell, 1965) were only partly incorporated into codes of welfare issued by the Ministry of Agriculture. The four original measures required were essentially a minimum floor space of $0.7 \mathrm{~m}^{2}$ for pigs growing from 68 to $90 \mathrm{~kg}$, adequate lighting for inspection of stock, no tail docking except for remedial treatment by a veterinary surgeon and that pregnant sows should be allowed exercise and should not be tethered indoors. Those familiar with the industry will know that all four aspects have been consistently disregarded. There are of course reasons, cost being among them, but is it really beyond our wit to provide a scientific base and workable guidelines to improve the lot of our livestock? Over the years I have seen many intensive units and I sometimes wonder what one should say to the town-dwelling youngster who loves animals and would like a career tending and caring for them in the countryside.

We must not forget that in a democratic society people have a right to know and indeed to say, how their food is produced. Sir Kenneth Blaxter at a recent meeting of the British Veterinary Association pointed out that animal welfare is a moral issue, a decision between right and wrong. The problem is how is society to make these judgements and how can they be implemented fairly? In my view, those in contact with industrialized animal production can as easily fall into the trap of becoming brutalized and indifferent to animal suffering as those who are not familiar with animals can make the mistake of making anthropocentric judgements. Whilst some may become impatient with the extreme conclusions of the animal rights movement, I believe that one would have to be very insensitive indeed not to find something to be sympathetic with in the writings of some of its exponents such as Professor Singer's Animal Liberation (Singer, I976). There is a simple logic in the view that says if there are human rights then there are animal rights. 


\section{Conclusions}

Dr Braude in 1970 considered that the future of the pig was 'rosy'. Of course, it still is because the pig is the most tolerant and versatile of livestock and combines this with an outstanding efficiency of resource utilization which can be increased still further.

In the developing countries, I believe that the virtues which Gervase Markham saw in the pig nearly four centuries ago are the ones that will matter for a long time to come. The urbanized countries such as Britain have a rather different problem because we are already too far along the road towards industrialized livestock production to turn back. It is in this area that I see some 'black spots' on the 'rose' mentioned by Dr Braude.

Pig meat is not indispensable to a satisfactory diet. If people modify their view of the ethics of the production process, then reduced consumption may become established. Horses, dogs and perhaps rabbits do not feature as major meat producing species in the UK for psychological reasons which would be difficult to change. The advent of improved meat substitutes and other dietary options give consumers a freedom which is unparalleled in history. I suspect that society does not want cheap bacon at any cost to the environment or animal. The era of improving efficiency may have to be superseded by the era of better pollution control, improvement of the working environment of the stockman and achieving reasonable living standards for the pig.

I sincerely hope that the very real gains made in nutrition and health of pigs, in which Dr Braude has played such a prominent role, are not dissipated either by a loss of status by the industry due to its failure to devise systems which are ethically sound, nor by society failing to recognize that improvement will cost something in terms of the price of meat and in the acquisition of the knowledge required to make the changes effective.

\section{REFERENCES}

Brambell, F. W. R. (1965). Report of the Technical Committee to Enquire into the Welfare of Animals kept under Intensive Livestock Husbandry Systems. (Cmnd 2836) London: HM Stationery Office.

Braude, R. (1970). Proc. Nutr. Soc. 29, 262.

Carson, R. (1963). Silent Spring. London: Hamilton.

Central Statistical Office (1979). Annual Abstract of Statistics. London: HM Stationery Office.

Food and Agriculture Organization (1979). FAO production yearbook, 32, Rome: FAO (FAO Statistics Series No. 22).

Fowler, V. R., Bichard, M. \& Pease, A. H. (1976). Anim. Prod. 23, 365.

Harrison, R. (1964). Animal Machines. London: Vincent Stuart.

Hobson, P. N., Bousfield, S., Summers, R. \& Mills, P. J. (1979). In Engineering Problems with Effluents from Livestock, p. 492. [J. C. Hawkins, editor]. Luxembourg: Commission of the European Communities.

Holmes, W. (1971). In Potential Crop Production, p. 213. [P. F. Wareing and J. P. Cooper, editors]. London: Heinemann.

Huxley, E. ( $\left.196_{5}\right)$. Brave New Victuals. An inquiry into modern food production. London: Chatto and Windus.

Kornberg, H. (1979). Royal Commission on Environmental Pollution. Seventh Report: Agriculture and Pollution. (Cmnd 7644) London: HM Stationery Office. 
Livingstone, R. M. \& Jones, A. S. (1977). Anim. Feed Sci. Technol. 2, 277.

Livingstone, R. M., Jones, A. S. \& Mennie, I. (1977). Anim. Feed Sci. Technol. 2, 31.

MacPherson, R. M., Hovell, F. D. DeB. \& Jones, A. S. (1977). Anim. Prod. 24, 333.

Markham, G. (1614). 'Cheape and Good Husbandry'.

Meat \& Livestock Commission (1978). Commercial Product Evaluation. Fourth test report. Milton Keynes: Meat \& Livestock Commission.

Singer, P. (1976). Animal Liberation. London: Granada.

Smith, C. \& Fowler, V. R. (1979). Livest. Prod. Sci. 5, 415.

White, D. J. (1975). Agricultural Engineer 30, 52. 